\title{
Indexes of Radicle are Sensitive and Effective for Assessing Copper and Zinc Tolerance in Germinating Seeds of Suaeda salsa
}

\author{
Hao Zhang ${ }^{1,2}$, Li Jiang ${ }^{1}$, Mohsin Tanveer ${ }^{3} \mathbb{C}$, Jinbiao Ma ${ }^{1}$, Zhenyong Zhao ${ }^{1,2}$ and Lei Wang ${ }^{1,2, *(\mathbb{D})}$ \\ 1 State Key Laboratory of Desert and Oasis Ecology, Xinjiang Institute of Ecology and Geography, \\ Chinese Academy of Sciences, Urumqi 830011, China; Zh15553531808@163.com (H.Z.); jiangli@ms.xjb.ac.cn (L.J.); \\ majinbiao@ms.xjb.ac.cn (J.M.); zhaozhy@ms.xjb.ac.cn (Z.Z.) \\ 2 University of Chinese Academy of Sciences, Beijing 100049, China \\ 3 Tasmanian Institute of Agriculture, University of Tasmania, Hobart 7005, Australia; mohsin.tanveer@utas.edu.au \\ * Correspondence: egiwang@ms.xjb.ac.cn; Tel.: +86-0991-7823189
}

Received: 24 August 2020; Accepted: 28 September 2020; Published: 30 September 2020

check for updates

\begin{abstract}
Euhalophytes, such as Suaeda salsa, are ideal candidates to remediate heavy metal-polluted saline soils. However, the metal tolerance ability of dimorphic seeds and subsequent seedlings is largely unknown. This study investigated the tolerance of $S$. salsa seeds to different concentrations of $\mathrm{Cu}^{2+}$ $(0-300 \mathrm{mM})$ and $\mathrm{Zn}^{2+}(0-300 \mathrm{mM})$ during germination and seedling growth stages. Results showed that dimorphic seeds of $S$. salsa had high metal tolerance during germination, and even germinated under $300 \mathrm{mM} \mathrm{Cu}$ and $\mathrm{Zn}$ treatments. However, seedling growth was more sensitive to metal solutions and radicle growth was almost completely inhibited by $\mathrm{Cu}$ at $10 \mathrm{mM}$, and by $\mathrm{Zn}$ at $50 \mathrm{mM}$. Germinating seeds and seedlings of $S$. salsa had a higher metal toxicity threshold of $\mathrm{Zn}$ than that of $\mathrm{Cu}$. In all indexes, indexes of radicle were the most sensitive and effective indicator of metal tolerance. Seeds of $S$. salsa germinated successfully and seedlings survived under high $\mathrm{Zn}$ and $\mathrm{Cu}$ stress. The results suggest that $S$. salsa could be sown directly in heavy metal-contaminated soils for phytoremediation.
\end{abstract}

Keywords: dimorphic seed; germination index; halophyte; phytoremediation; seedling growth; Suaeda salsa

\section{Introduction}

Heavy metal pollution is a great environmental threat that reduces plant productivity [1]. With the rapid development of industry and agriculture worldwide, heavy metal-contaminated soil has become a serious environmental problem [2]. Polluted soils not only lead to deleterious effects on plants, but also pose human health risks via direct ingestion, contact with polluted soil, and the food chain $[3,4]$. In recent years, saline soils, including those in coastal areas and arid regions, are influenced by heavy metals [5-7]. Developing halophyte remediation technologies may help solve this problem [8,9]. The first critical step of phytoremediation is seedling emergence in the heavy metal-contaminated soils. Halophytes generally exhibit high salt tolerance during germination and seedling establishment. However, their ability to tolerate high levels of heavy metals is still largely unknown.

Seed germination is a critical transition because dry seeds are the most tolerant of and seedlings are the most sensitive to environmental stresses [10]. During the germination stage, seed germination percentage and velocity decrease with the increase in heavy metal concentrations [11,12]. Furthermore, seedling growth parameters are even more sensitive to heavy metal stress [13-15]. There are few studies on the inhibition of seed germination and seedling growth thereafter on wild species caused by heavy metals $[6,16]$. For example, seeds of several Australian native species, namely Astrebla lappacea, 
Themeda australis, Austrostipa scabra and Acacia harpophylla, were placed in different concentrations of arsenic (As), copper $(\mathrm{Cu})$, zinc $(\mathrm{Zn})$, manganese $(\mathrm{Mn})$ and lead $(\mathrm{Pb})$ to test their tolerance ability during germination and seedling growth stages [14].

$\mathrm{Cu}$ and $\mathrm{Zn}$ are essential micronutrients for plants at low levels of concentration, but they are toxic and retard growth or even cause death for most plant species at higher concentrations [11,17]. When in excess, $\mathrm{Zn}$ limits plant growth of root and expansion of leaves. $\mathrm{Cu}$ toxicity is characterized by chlorosis of leaves and the inhibition of root growth [18]. Cu and $\mathrm{Zn}$ toxicity have been reported for many plants, including many economically important crops. It has been reported that some plants have a high tolerance to $\mathrm{Cu}$ and $\mathrm{Zn}$, and even accumulate large amounts of them in aboveground tissues $[19,20]$.

Euhalophyte Suaeda salsa grows in inland saline soils and intertidal regions. This plant species has a high salt tolerance during its whole life cycle, from the germination phase to the fruiting phase [21]. In intertidal regions, S. salsa even can form a monospecific community. It can also absorb and accumulate different heavy metals, such as $\mathrm{As}, \mathrm{Pb}$, chromium $(\mathrm{Cr})$ and $\mathrm{Cu}[7,17]$. $\mathrm{NaCl}$ improved translocation and accumulation of $\mathrm{Pb}$ in $\mathrm{S}$. salsa under $\mathrm{Pb}$ stress, thus enhancing the phytoextraction of $\mathrm{Pb}$ [22]. This species produces two types of seeds that differ in seed color, seed morph, dormancy type and germination characteristics. As Cu-tolerant halophytes, S. salsa plants grown from dimorphic seeds have different salt tolerances but exhibit similar responses to $\mathrm{Cu}$ [23]. Dimorphic seeds of $S$. salsa can germinate under a high $\mathrm{NaCl}$ concentration, and brown seeds have a higher germination percentage and velocity under salt stress during germination [21,24]. Although several studies have tested the tolerance ability of $S$. salsa seeds to different heavy metals [25,26], little information is known regarding the effect of seed type on heavy metal tolerance of $S$. salsa.

To evaluate the heavy metal tolerance of germinating seeds correctly, it is necessary to select an effective index. Though germination percentage and germination velocity are common indicators, several research studies suggest that indexes related to young seedlings are more suitable for metal tolerance analyses $[6,14]$. Thus, in this study, we selected two indexes for germinating seeds and four indexes for seedling establishment. The goal of this study was to determine the effect of $\mathrm{Cu}$ and Zn stress on the halophyte $S$. salsa at the germination and early seedling growth stages. Specifically, we asked the following questions: (1) Do dimorphic seeds of $S$. salsa have the same metal tolerance during germination? (2) Which index is more suitable for the proper analysis of heavy metal tolerance? (3) Does $\mathrm{Cu}$ exhibit stronger toxicity than $\mathrm{Zn}$ at the same concentrations?

\section{Materials and Methods}

\subsection{Plant Materials}

Mature fruits of $S$. salsa were collected from at least 50 plants growing in a salt desert in Karamay (North Xinjiang, China) in November 2019. Vegetation consists of plant species such as Suaeda aralocaspica, Salsola subcrassa and Phragmites australis. This site belongs to a temperate continental desert arid climate. The annual average temperature is $8.1^{\circ} \mathrm{C}$. The mean annual precipitation is $105 \mathrm{~mm}$ and mean annual potential evaporation is $3545 \mathrm{~mm}$.

The fruits were allowed to dry naturally for 2 weeks in laboratory room. Seeds were separated from the dried plant material and sorted into brown seeds and black seeds. Each type of seed was pooled and stored at room temperature until used in experiments.

\subsection{Chemicals}

Water-soluble metal compounds were used throughout. $\mathrm{CuSO}_{4} \cdot 5 \mathrm{H}_{2} \mathrm{O}$ and $\mathrm{ZnSO}_{4} \cdot 7 \mathrm{H}_{2} \mathrm{O}$ were purchased from Fuchen Chemical Reagent Co., Ltd. (Tianjin, China).

\subsection{Germination Experiment}

Effects of different concentrations of $\mathrm{Cu}$ and $\mathrm{Zn}$ on the germination of dimorphic seeds of S. salsa were evaluated using single metal solutions prepared in deionized water. For each treatment, 
four replicates of 25 seeds were incubated in $50 \mathrm{~mm}$ diameter Petri dishes on two layers of No. 1 filter paper moistened with $2.5 \mathrm{~mL}$ of distilled water or with different concentrations $(0.01,0.05,0.1,0.5,1,5$, 10, 50, 100, 150, 200, 250 and $300 \mathrm{mM}$ ) of $\mathrm{Cu}$ and $\mathrm{Zn}$. To avoid evaporation, after being covered with lids, the edges of the Petri dishes were sealed with Parafilm. Then, the Petri dishes were transferred to light incubator chamber (GXZ-380, Jiangnan Instrument Factory, Zhejiang, China) and incubated at daily (12/12-h) temperature regimes of 10: $25{ }^{\circ} \mathrm{C}$ under a $12 \mathrm{~h}$ daylight photoperiod for 20 days. The dishes were opened daily to count the number of germinated seedlings. Because black seeds are smaller and the seed coat of black seeds is more rigid than that of brown seeds, the germination test standards for them are different. For black seeds, the radicle was $\geq 1 \mathrm{~mm}$. For brown seeds, the radicle was $\geq 2 \mathrm{~mm}$. Germination percentage $(\%)=$ (the number of seeds germinated in different metal solutions/total number of seeds tested) $\times 100$. The velocity of germination was estimated using a modified Timson's index of germination velocity [27].

\subsection{Seedling Incubation}

For the first week of the germination experiment, at each counting, germinated seeds were transferred into new Petri dishes ( $90 \mathrm{~mm}$ diameter) with the same solutions under the same temperature and light conditions. Incubation of the seedlings was terminated at the end of the germination experiment. Radicle length and shoot length were measured for 20 randomly selected seedlings under a microscope with Olympus CellSens software. Radicle tolerance index $(\%)=($ mean length of the radicle in metal treatment/mean length of the radicle in distilled water control) $\times 100$. Shoot tolerance index $(\%)=($ mean length of the shoot in metal treatment/mean length of the shoot in distilled water control) $\times 100$.

\subsection{Data Analysis}

Data for germination percentage, germination index, shoot and radicle tolerance index were analyzed by linear regression using the enter linear regression method (all independent variables were entered into the equation in a single step). The multiple linear regression model included seed type (brown and black seeds), heavy metal type ( $\mathrm{Cu}$ and $\mathrm{Zn}$ ) and metal concentration $(0,0.01,0.05,0.1$, $0.5,1,5,10,50,100,150,200,250$ and $300 \mathrm{mM})$. All statistical analyses were conducted using SPSS 16.0 (SPSS, Inc., Chicago, IL, USA). All data were expressed as means \pm SE. One-way ANOVA and Turkey's test were used to determine significant differences among different concentrations of $\mathrm{Cu}$ or $\mathrm{Zn}$ treatments for different indexes of each seed type of $S$. salsa. Independent samples T-Test was used to determine whether there was a difference between dimorphic seeds for different indexes of at the same $\mathrm{Cu}$ or $\mathrm{Zn}$ concentrations.

\section{Results}

\subsection{Germination}

Germination percentage and germination index were significantly affected by seed type $(p<0.001)$, metal type $(p<0.001)$ and metal concentration $(p<0.001)$ (Table 1$)$.

Germination percentages of brown seeds in all Cu treatments ranged from $38 \%$ to $100 \%$, whereas those of black seeds were $51-83 \%$ (Table 2). In other words, germination percentages of brown seeds were higher than that of black seeds at a low $\mathrm{Cu}$ concentration, similar to that of black seeds at a medium concentration, and lower at a high concentration. Germination percentages of dimorphic seeds in $\mathrm{Zn}$ solutions showed a similar trend. Germination indexes of brown seeds in all $\mathrm{Cu}$ treatments were $36.2-98.2 \%$, whereas those of black seeds were $30.9-61.1 \%$ (Table 3). Germination indexes of brown seeds in all Zn treatments were 52.1-98\%, whereas those of black seeds were 50.5-61\%. At the same $\mathrm{Cu}$ or $\mathrm{Zn}$ concentration, the germination index of brown seeds was significantly higher than that of black seeds (Table 3). 
Table 1. Multivariate analysis of correlates associated with germination percentage and index of dimorphic seeds of Suaeda salsa, radicle and shoot length of seedlings grown from both types of seeds.

\begin{tabular}{ccccc}
\hline Index & Factor & B (SE) & $\beta$ & $p$-Value \\
\hline \multirow{2}{*}{ Germination } & Metal type & $8.607(1.561)$ & 0.259 & $<0.001$ \\
percentage & Seed type & $-10.036(1.561)$ & -0.302 & $<0.001$ \\
& Solution concentration & $-0.097(0.008)$ & -0.598 & $<0.001$ \\
\hline \multirow{2}{*}{ Germination index } & Metal type & $8.471(1.41)$ & 0.199 & $<0.001$ \\
& Seed type & $-29.421(1.41)$ & -0.692 & $<0.001$ \\
& Solution concentration & $-0.102(0.007)$ & -0.489 & $<0.001$ \\
\hline \multirow{2}{*}{ Radicle length } & Metal type & $1.137(0.209)$ & 0.143 & $<0.001$ \\
& Seed type & $-1.651(0.209)$ & -0.208 & $<0.001$ \\
& Solution concentration & $-0.016(0.001)$ & -0.404 & $<0.001$ \\
\hline \multirow{2}{*}{ Shoot length } & Metal type & $1.102(0.14)$ & 0.158 & $<0.001$ \\
& Seed type & $-1.394(0.14)$ & -0.201 & $<0.001$ \\
& Solution concentration & $-0.024(0.001)$ & -0.695 & $<0.001$ \\
\hline
\end{tabular}

Table 2. Effect of $\mathrm{CuSO}_{4}$ and $\mathrm{ZnSO}_{4}$ on germination percentage of dimorphic seeds of $S$. salsa.

\begin{tabular}{ccccc}
\hline \multirow{2}{*}{ Concentration (mM) } & \multicolumn{2}{c}{$\mathrm{CuSO}_{4}$} & \multicolumn{2}{c}{$\mathrm{ZnSO}_{4}$} \\
\cline { 2 - 5 } & Brown Seed & Black Seed & Brown Seed & Black Seed \\
\hline 0 & $100.0 \pm 0.0 \mathrm{Aa}$ & $74.0 \pm 2.6 \mathrm{Bab}$ & $100.0 \pm 0.0 \mathrm{Aa}$ & $82.0 \pm 2.6 \mathrm{Ba}$ \\
0.01 & $100.0 \pm 0.0 \mathrm{Aa}$ & $71.0 \pm 1.9 \mathrm{~B} \mathrm{Abc}$ & $99.0 \pm 1.0 \mathrm{Aa}$ & $72.0 \pm 5.4 \mathrm{Ba}$ \\
0.05 & $96.0 \pm 1.6 \mathrm{Aab}$ & $77.0 \pm 4.4 \mathrm{Bab}$ & $100.0 \pm 0.0 \mathrm{Aa}$ & $68.0 \pm 2.3 \mathrm{Ba}$ \\
0.1 & $99.0 \pm 1.0 \mathrm{Aab}$ & $73.0 \pm 3.4 \mathrm{Bab}$ & $98.0 \pm 1.2 \mathrm{Aa}$ & $69.0 \pm 5.7 \mathrm{Ba}$ \\
0.5 & $100.0 \pm 0.0 \mathrm{Aa}$ & $83.0 \pm 2.5 \mathrm{Ba}$ & $99.0 \pm 1.0 \mathrm{Aa}$ & $81.0 \pm 1.9 \mathrm{Ba}$ \\
1 & $98.0 \pm 1.2 \mathrm{Aab}$ & $73.0 \pm 6.6 \mathrm{Bab}$ & $99.0 \pm 1.0 \mathrm{Aa}$ & $80.0 \pm 5.2 \mathrm{Ba}$ \\
5 & $81.0 \pm 5.7 \mathrm{Ac}$ & $70.0 \pm 4.8 \mathrm{Aabc}$ & $99.0 \pm 1.0 \mathrm{Aa}$ & $76.0 \pm 0.0 \mathrm{Ba}$ \\
10 & $85.0 \pm 3.8 \mathrm{Abc}$ & $71.0 \pm 4.1 \mathrm{Babc}$ & $98.0 \pm 1.2 \mathrm{Aa}$ & $81.0 \pm 5.5 \mathrm{Aa}$ \\
50 & $73.0 \pm 4.4 \mathrm{Acd}$ & $66.0 \pm 5.3 \mathrm{Aabc}$ & $78.0 \pm 2.0 \mathrm{Ab}$ & $77.0 \pm 3.0 \mathrm{Aa}$ \\
100 & $61.0 \pm 1.0 \mathrm{Ade}$ & $57.0 \pm 5.7 \mathrm{Abc}$ & $70.0 \pm 3.8 \mathrm{Abc}$ & $82.0 \pm 5.0 \mathrm{Aa}$ \\
150 & $55.0 \pm 1.0 \mathrm{Be}$ & $63.0 \pm 1.0 \mathrm{Aabc}$ & $77.0 \pm 4.7 \mathrm{Ab}$ & $82.0 \pm 2.6 \mathrm{Aa}$ \\
200 & $55.0 \pm 2.5 \mathrm{Ae}$ & $51.0 \pm 3.4 \mathrm{Ac}$ & $69.0 \pm 3.4 \mathrm{Abc}$ & $79.0 \pm 5.3 \mathrm{Aa}$ \\
300 & $63.0 \pm 3.0 \mathrm{Ade}$ & $64.0 \pm 3.7 \mathrm{Aabc}$ & $66.0 \pm 4.2 \mathrm{Abc}$ & $77.0 \pm 1.9 \mathrm{Aa}$ \\
& $38.0 \pm 4.8 \mathrm{Bf}$ & $52.0 \pm 2.3 \mathrm{Ac}$ & $54.0 \pm 10.5 \mathrm{Ac}$ & $78.0 \pm 4.8 \mathrm{Aa}$ \\
\hline
\end{tabular}

The standard error annotated by different lower-case letters among different concentration for the same seed type and metal type indicate significant differences at $p<0.05$, Tukey's post hoc test. The standard errors annotated by different higher-case letters between dimorphic seeds at the same concentration of $\mathrm{Cu}$ or $\mathrm{Zn}$ indicate significant differences at $p<0.05$, Tukey's post hoc test.

For each seed type, at the same concentration, seeds generally had a higher germination percentage and index in $\mathrm{Zn}$ solution than in Cu solution. For example, germination of brown seeds was 99\% at $5 \mathrm{mM} \mathrm{Zn}$ solution, whereas only $81 \%$ germination was reached at $5 \mathrm{mM} \mathrm{Cu}$ solution (Table 2). Germination index of black seeds reached $53.9 \%$ at the highest level of $\mathrm{Zn}$ toxicity ( $300 \mathrm{mM}$ ), but the germination index of black seeds was only $30.9 \%$ at the same level of Cu toxicity (Table 3).

As $\mathrm{Cu}$ concentration increased from 0 to $300 \mathrm{mM}$, germination percentage and germination index of dimorphic seeds decreased (Tables 2 and 3). For brown seeds, germination percentage decreased from $100 \%$ at control to $38 \%$ at $300 \mathrm{mM}$. There was a different trend for the germination responses of dimorphic seeds in $\mathrm{Zn}$ solutions. The germination percentage and germination index of brown seeds also showed a decline trend as in $\mathrm{Cu}$ solutions. However, for black seeds, germination percentages and germination indexes did not show a significant difference among different $\mathrm{Zn}$ concentrations (Tables 2 and 3 ). 
Table 3. Effect of $\mathrm{CuSO}_{4}$ and $\mathrm{ZnSO}_{4}$ on germination index of dimorphic seeds of S. salsa.

\begin{tabular}{ccccc}
\hline \multirow{2}{*}{ Concentration(mM) } & \multicolumn{2}{c}{$\mathrm{CuSO}_{4}$} & \multicolumn{2}{c}{ ZnSO $_{4}$} \\
\cline { 2 - 5 } & Brown Seed & Black Seed & Brown Seed & Black Seed \\
\hline 0 & $97.6 \pm 0.4 \mathrm{Aa}$ & $49.0 \pm 2.4 \mathrm{~B} \mathrm{Abcd}$ & $97.4 \pm 0.2 \mathrm{Aa}$ & $60.9 \pm 2.2 \mathrm{Ba}$ \\
0.01 & $97.8 \pm 0.1 \mathrm{Aa}$ & $51.0 \pm 1.0 \mathrm{~B} \mathrm{Abc}$ & $96.5 \pm 1.1 \mathrm{Aa}$ & $52.6 \pm 4.3 \mathrm{Ba}$ \\
0.05 & $93.5 \pm 1.2 \mathrm{~A} \mathrm{Ab}$ & $56.2 \pm 2.8 \mathrm{Bab}$ & $98.0 \pm 0.4 \mathrm{Aa}$ & $50.5 \pm 2.4 \mathrm{Ba}$ \\
0.1 & $96.0 \pm 0.7 \mathrm{Aa}$ & $50.3 \pm 2.3 \mathrm{Babc}$ & $95.8 \pm 1.0 \mathrm{Aa}$ & $51.1 \pm 4.1 \mathrm{Ba}$ \\
0.5 & $98.2 \pm 0.1 \mathrm{Aa}$ & $61.1 \pm 2.5 \mathrm{Ba}$ & $96.0 \pm 1.1 \mathrm{Aa}$ & $58.7 \pm 1.6 \mathrm{Ba}$ \\
1 & $96.5 \pm 1.1 \mathrm{Aa}$ & $51.9 \pm 5.2 \mathrm{~B} \mathrm{Ab}$ & $96.9 \pm 1.0 \mathrm{Aa}$ & $58.2 \pm 4.8 \mathrm{Ba}$ \\
5 & $78.1 \pm 5.2 \mathrm{Ac}$ & $49.8 \pm 4.6 \mathrm{~B} \mathrm{Abc}$ & $97.2 \pm 1.1 \mathrm{Aa}$ & $56.9 \pm 0.9 \mathrm{Ba}$ \\
10 & $81.2 \pm 3.9 \mathrm{Abc}$ & $47.5 \pm 3.9 \mathrm{~B} \mathrm{Abcd}$ & $94.9 \pm 1.5 \mathrm{Aa}$ & $61.0 \pm 3.9 \mathrm{Ba}$ \\
50 & $70.5 \pm 4.1 \mathrm{Acd}$ & $44.2 \pm 3.7 \mathrm{Bbcde}$ & $76.4 \pm 2.2 \mathrm{Ab}$ & $53.0 \pm 3.0 \mathrm{Ba}$ \\
100 & $56.7 \pm 1 \mathrm{Ae}$ & $35.4 \pm 5.5 \mathrm{Bbcde}$ & $68.2 \pm 3.9 \mathrm{Abc}$ & $57.2 \pm 3.9 \mathrm{Aa}$ \\
150 & $52.0 \pm 0.7 \mathrm{Ae}$ & $41.3 \pm 0.5 \mathrm{Bde}$ & $74.5 \pm 4.1 \mathrm{Ab}$ & $57.5 \pm 2.0 \mathrm{Ba}$ \\
200 & $52.6 \pm 2.3 \mathrm{Ae}$ & $33.1 \pm 1.8 \mathrm{Bde}$ & $66.9 \pm 3.5 \mathrm{Abc}$ & $50.5 \pm 2.9 \mathrm{Ba}$ \\
250 & $59.0 \pm 2.7 \mathrm{Ade}$ & $42.6 \pm 2.2 \mathrm{Bbcde}$ & $63.9 \pm 3.9 \mathrm{Abc}$ & $50.7 \pm 1.3 \mathrm{Ba}$ \\
300 & $36.2 \pm 4.3 \mathrm{Af}$ & $30.9 \pm 1.2 \mathrm{Ae}$ & $52.1 \pm 10.0 \mathrm{Ac}$ & $53.9 \pm 2.6 \mathrm{Aa}$ \\
\hline
\end{tabular}

The standard errors annotated by different lower-case letters among different concentrations for the same seed type and metal type indicate significant differences at $p<0.05$, Tukey's post hoc test. The standard errors annotated by different higher-case letters between dimorphic seeds at the same concentration of $\mathrm{Cu}$ or $\mathrm{Zn}$ indicate significant differences at $p<0.05$, Tukey's post hoc test.

\subsection{Seedling Growth}

Radicle and shoot lengths were significantly affected by seed type $(p<0.001)$, heavy metal type $(p<0.001)$ and metal concentration $(p<0.001)$ (Table 1$)$.

Brown seeds generally had higher shoot lengths than black seeds in the same $\mathrm{Cu}$ or $\mathrm{Zn}$ solutions (Figures 1 and 2). Radicle lengths of brown seeds in all $\mathrm{Cu}$ treatments were 2.2-14.3 mm, whereas those of black seeds were 1.2-8.3 mm (Figure 1). Radicle length of brown seeds was higher than that of black seeds at the same $\mathrm{Cu}$ concentrations. Similarly, the radicle of brown seeds had higher length growth than that of black seeds in the same Zn solutions (Figure 2).

For each seed type, at the same concentration, seeds generally had higher lengths and better growth of radicles and shoots in $\mathrm{Zn}$ solution than that in $\mathrm{Cu}$ solution. For example, the radicle length of brown seeds was $10.0 \mathrm{~mm}$ at $0.1 \mathrm{mM} \mathrm{Zn}$ solution, whereas it was only $4.4 \mathrm{~mm}$ at the same concentration of $\mathrm{Cu}$. Radicle growth was almost completely inhibited by $\mathrm{Cu}$ at $10 \mathrm{mM}$, and by $\mathrm{Zn}$ at $50 \mathrm{mM}$ (Figures 3 and 4). 


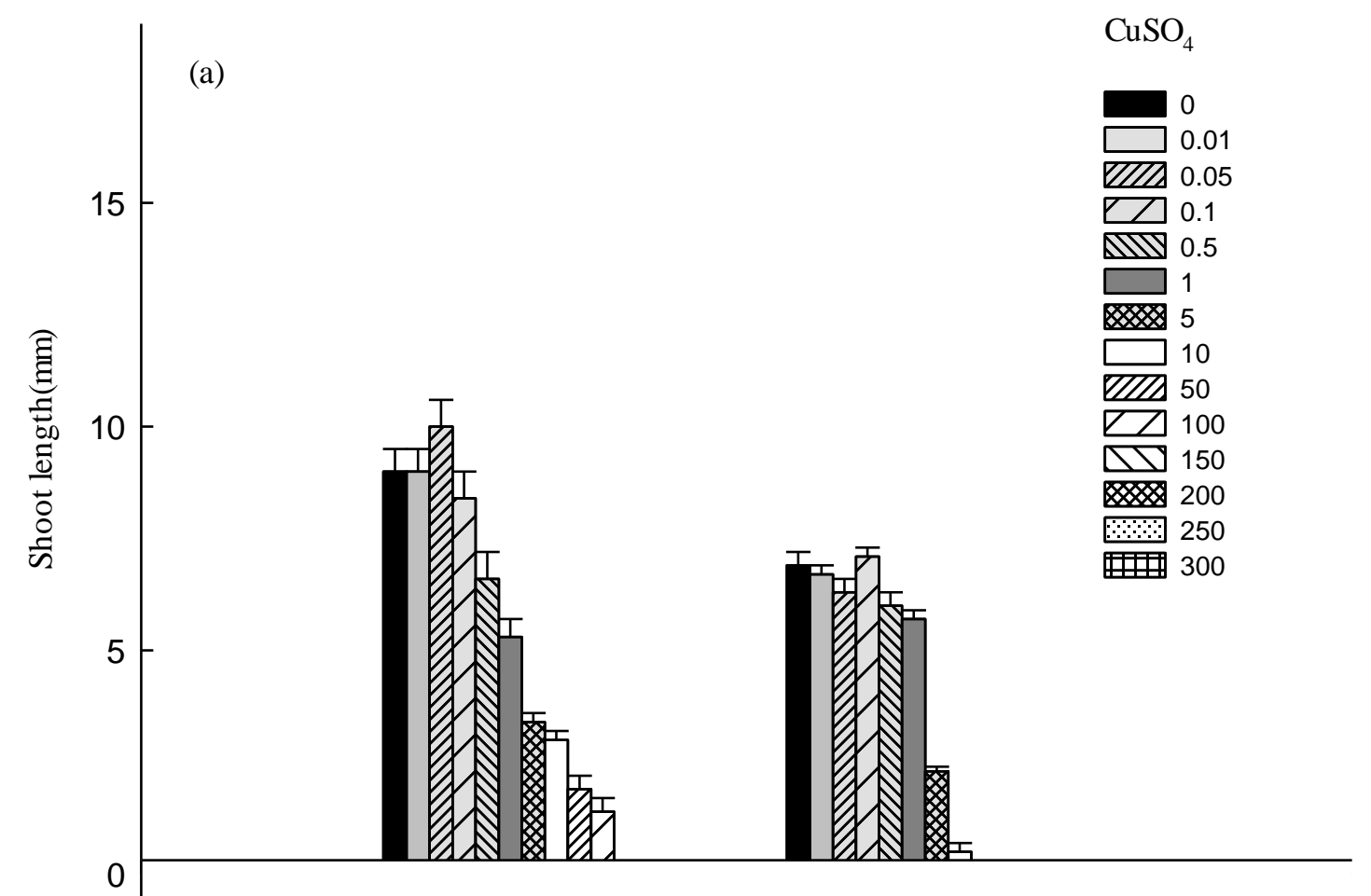

(b)

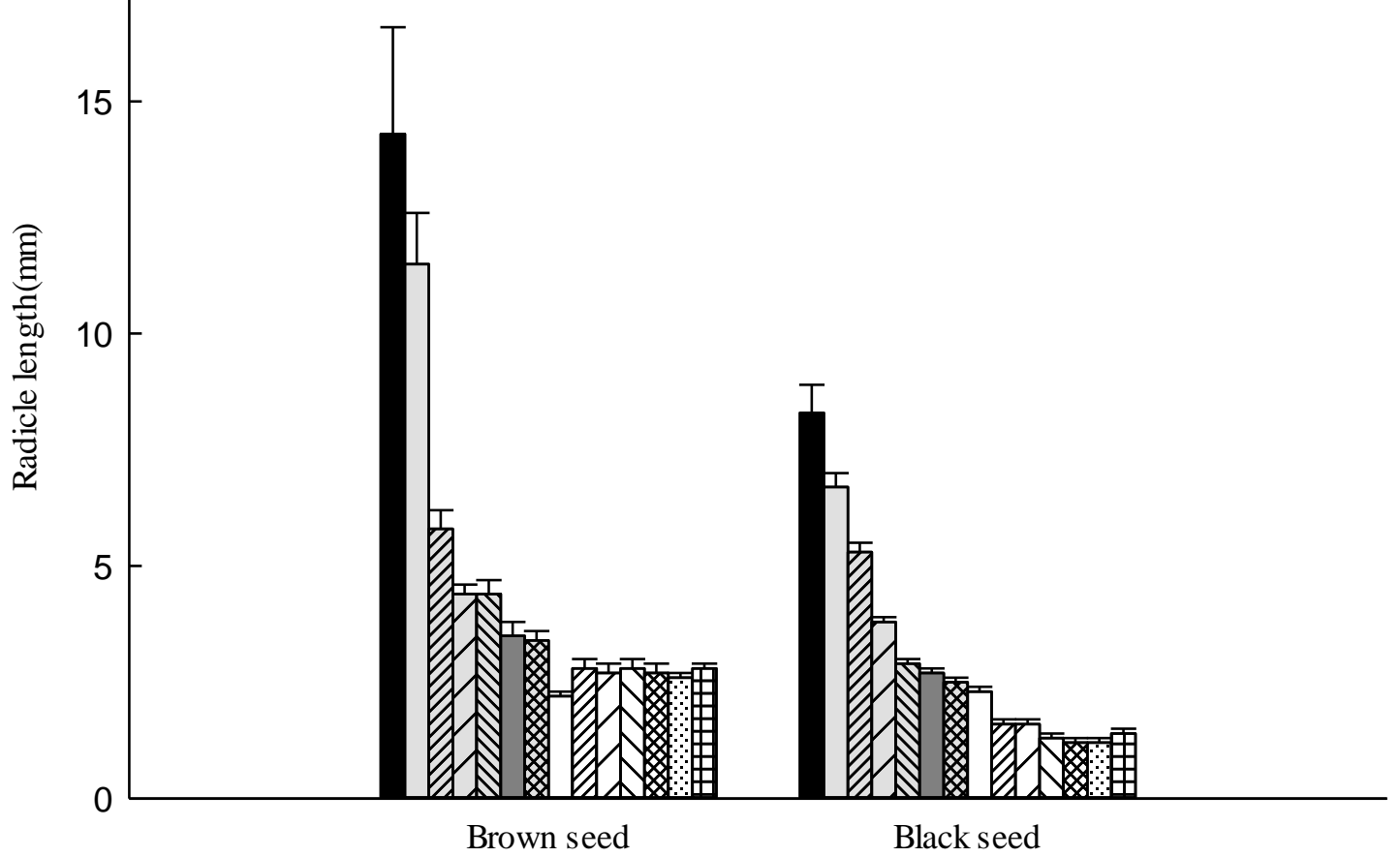

Figure 1. Effect of $\mathrm{Cu}$ on (a) shoot and (b) radicle length of seedlings grown from dimorphic seeds of S. salsa. 


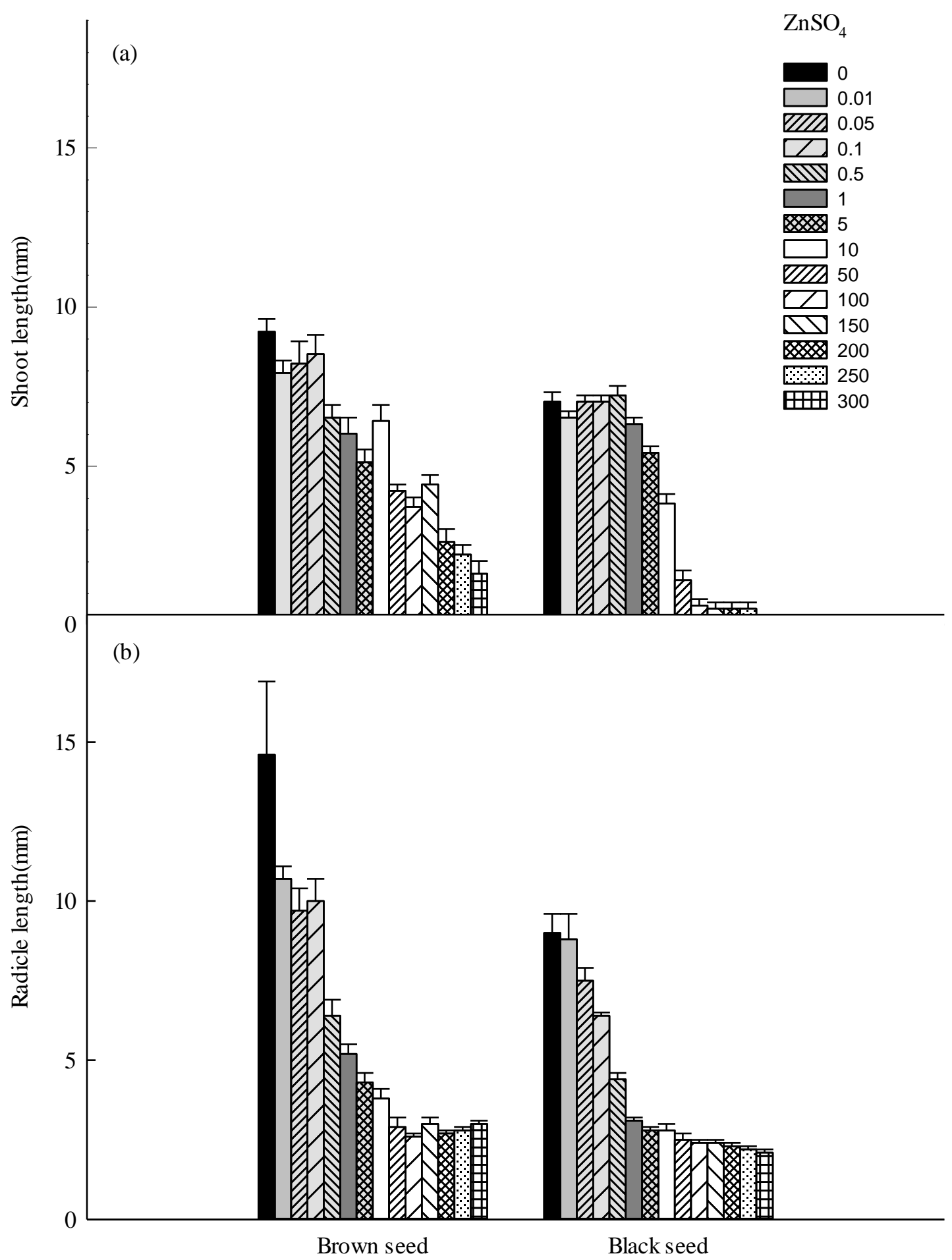

Figure 2. Effect of $\mathrm{Zn}$ on (a) shoot and (b) radicle length of seedlings grown from dimorphic seeds of S. salsa. 


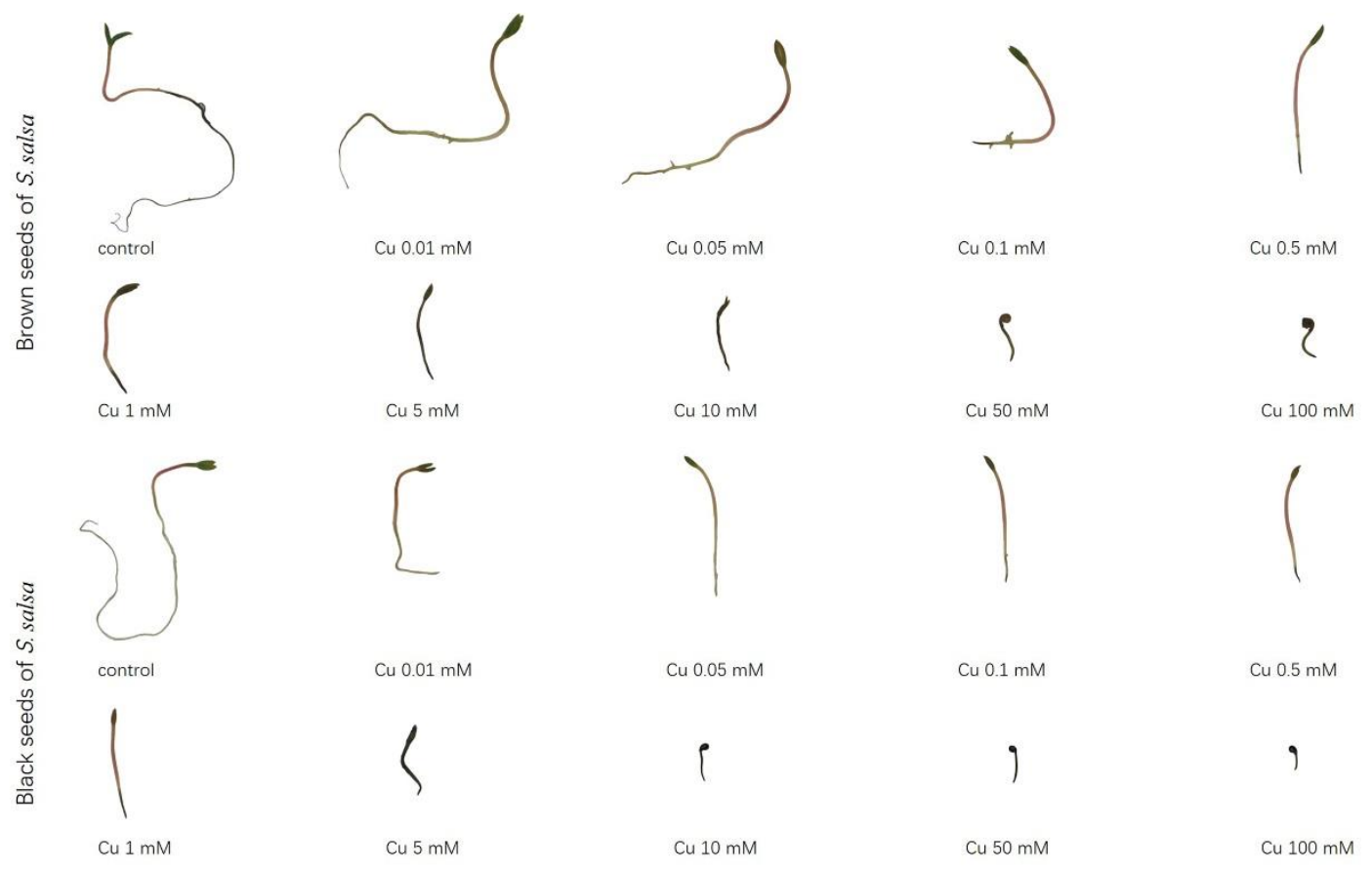

Figure 3. Radicle elongation of seedlings grown from dimorphic seeds of S. salsa after 20 days in various concentrations of $\mathrm{Cu}$ solutions.
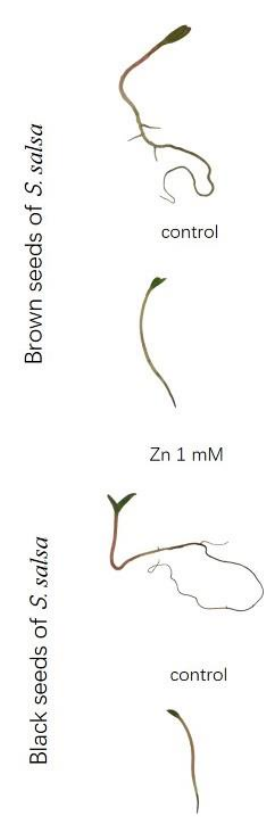

$\mathrm{Zn} 1 \mathrm{mM}$
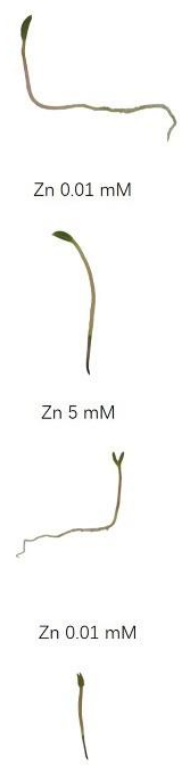

Zn $5 \mathrm{mM}$
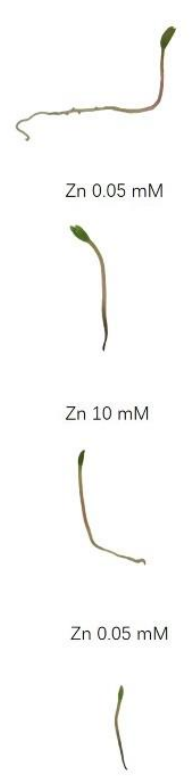

$\mathrm{Zn} 10 \mathrm{mM}$
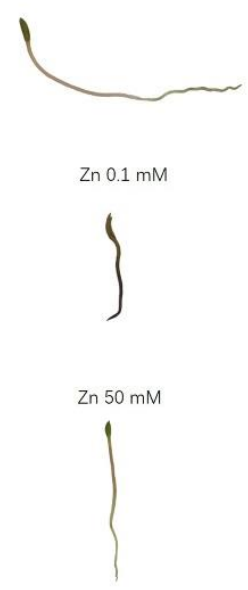

Zn $0.1 \mathrm{mM}$

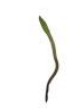

Zn $50 \mathrm{mM}$

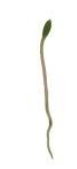

Zn $0.5 \mathrm{mM}$

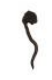

Zn 100 mM

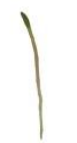

Zn $0.5 \mathrm{mM}$

;

Zn 100 mM

Figure 4. Radicle elongation of seedlings grown from dimorphic seeds of $S$. salsa after 20 days in various concentrations of $\mathrm{Zn}$ solutions.

The radicle and shoot length of seedlings grown from dimorphic seeds decreased with the increase of metal concentrations. Radicle length from brown seeds was significantly reduced compared to the control at $\mathrm{Cu}$ concentrations of $0.05 \mathrm{mM}$ and higher. Shoot length from brown seeds was not affected by $\mathrm{Cu}$ up to $0.1 \mathrm{mM}$ but it was significantly reduced at $0.5 \mathrm{mM}$ and progressively reduced further at higher concentrations compared to control (Figures 1 and 3). The decreasing trend of radicle and shoot lengths in $\mathrm{Zn}$ solutions was similarly observed in $\mathrm{Cu}$ solutions, but was less severe (Figure 2). 
The radicle tolerance index and the shoot tolerance index showed similar changes in radicle and shoot lengths (Tables 4 and 5). Both indexes were usually higher in $\mathrm{Zn}$ solutions. The radicle tolerance index was more sensitive to metal toxicity than the shoot tolerance index. The radicle tolerance index reached limitation values in relatively lower metal concentrations. For example, the limitation value for the radicle tolerance index of seedlings from brown seeds is $10 \mathrm{mM} \mathrm{Cu}$ concentration. However, for shoot tolerance index, it was $150 \mathrm{mM} \mathrm{Cu}$ concentration (Table 4).

Table 4. Effect of $\mathrm{CuSO}_{4}$ and $\mathrm{ZnSO}_{4}$ on the radicle tolerance index of $\mathrm{S}$. salsa seedlings grown from brown and black seeds.

\begin{tabular}{ccccc}
\hline \multirow{2}{*}{ Concentration (mM) } & \multicolumn{2}{c}{$\mathrm{CuSO}_{4}$} & \multicolumn{2}{c}{ ZnSO $_{4}$} \\
\cline { 2 - 5 } & Brown Seed & Black Seed & Brown Seed & Black Seed \\
\hline 0 & 100.00 & 100.00 & 100.00 & 100.00 \\
0.01 & 80.33 & 81.08 & 73.40 & 97.68 \\
0.05 & 40.53 & 63.80 & 66.88 & 83.18 \\
0.1 & 30.65 & 45.70 & 68.61 & 40.8 \\
0.5 & 30.66 & 34.71 & 43.82 & 34.83 \\
1 & 24.40 & 32.26 & 35.95 & 30.62 \\
5 & 23.77 & 29.59 & 29.53 & 30.73 \\
10 & 15.35 & 27.62 & 26.05 & 27.82 \\
50 & 19.25 & 18.93 & 19.68 & 26.07 \\
100 & 18.73 & 18.79 & 17.79 & 26.60 \\
150 & 19.52 & 16.23 & 20.62 & 26.06 \\
200 & 18.56 & 14.04 & 18.79 & 23.94 \\
250 & 17.91 & 14.95 & 18.91 & 23.03 \\
\hline
\end{tabular}

Table 5. Effect of $\mathrm{CuSO}_{4}$ and $\mathrm{ZnSO}_{4}$ on shoot tolerance index of $\mathrm{S}$. salsa seedlings grown from brown and black seeds.

\begin{tabular}{ccccc}
\hline \multirow{2}{*}{ Concentration (mM) } & \multicolumn{2}{c}{$\mathrm{CuSO}_{4}$} & \multicolumn{2}{c}{ ZnSO $_{4}$} \\
\cline { 2 - 5 } & Brown Seed & Black Seed & Brown Seed & Black Seed \\
\hline 0 & 100.00 & 100.00 & 100.00 & 100.00 \\
0.01 & 110.38 & 96.15 & 86.03 & 95.08 \\
0.05 & 95.48 & 91.51 & 88.74 & 99.15 \\
0.1 & 93.58 & 102.76 & 92.82 & 100.06 \\
0.5 & 72.58 & 87.00 & 71.07 & 102.76 \\
1 & 58.40 & 81.77 & 65.50 & 90.03 \\
5 & 37.51 & 33.47 & 54.97 & 76.59 \\
10 & 33.28 & 7.61 & 69.47 & 53.57 \\
50 & 21.58 & 0.00 & 45.73 & 19.57 \\
100 & 15.96 & 0.00 & 40.69 & 8.16 \\
150 & 0.00 & 0.00 & 47.44 & 7.73 \\
200 & 0.00 & 0.00 & 28.13 & 7.55 \\
250 & 0.00 & 0.00 & 23.56 & 7.42 \\
300 & 0.00 & 0.00 & 17.39 & 0.00 \\
\hline
\end{tabular}

\section{Discussion}

Although dormancy and germination of dimorphic seeds of $S$. salsa and eco-physiological responses of plants grown from dimorphic seeds to different environmental factors have been studied extensively $[5,21,23,24]$, our study is the first to analyze germination of dimorphic seeds and seedling growth thereafter in different heavy metal solutions. In addition, our data indicate that both types of seeds of $\mathrm{S}$. salsa have high $\mathrm{Cu}$ and $\mathrm{Zn}$ tolerance during the germination stage, and young seedling growth is a critical stage for metal tolerance. $\mathrm{Cu}$ is more toxic than $\mathrm{Zn}$ to germinating seeds, especially for 
radicle growth. The results suggest that seeds and seedlings of $S$. salsa are not only tolerant to high salinity but also to high levels of heavy metals, such as $\mathrm{Cu}$ and $\mathrm{Zn}$.

Dimorphic seeds of $S$. salsa displayed differential germination responses to $\mathrm{Cu}$ and $\mathrm{Zn}$ toxicity. The germination percentage of brown seeds reached $38 \%$ and $54 \%$ at $300 \mathrm{mM} \mathrm{Cu}$ and $\mathrm{Zn}$, respectively. However, germination of black seeds was $54 \%$ and $78 \%$. The germination difference of dimorphic seeds in metal solutions might be related to their differential salt tolerances. Brown seeds of $S$. salsa are more salt tolerant than black seeds [21]. The contrasting abiotic tolerances of dimorphic seeds are also found in other plant species, such as Bidens pilosa [28], as well as Arthrocnemum macrostachyum [29] and Torilis arvensis [30]. This might be due to the difference in antioxidant ability between dimorphic seeds [29]. Furthermore, the tolerance difference of dimorphic seeds to abiotic stresses even has a carry-over effect. For example, the differential salinity tolerance of dimorphic seeds of Suaeda splendens carried over from seeds to seedlings [31]. Radicle and shoot lengths of brown seeds are generally longer than those of black seeds of $S$. salsa under the same metal treatment, however, this might be caused by the size difference between dimorphic seeds and the delayed germination of black seeds. Besides, the radicle and shoot tolerance indexes did not show a clear difference in pattern for dimorphic seeds. Moreover, adult plants grown from dimorphic seeds of $S$. salsa exhibited similar eco-physiological responses to $\mathrm{Cu}$. Thus, heavy metal tolerance of seedlings between dimorphic seeds needs more indexes to evaluate.

$\mathrm{Cu}$ had more inhibitory effects on seed germination and, thereafter, seedlings of $S$. salsa compared to $\mathrm{Zn}$. $\mathrm{Cu}$ and $\mathrm{Zn}$ are essential micronutrients and are required for different physiological processes. However, at high concentrations, both metals stimulate the production of ROS (Reactive oxygen species) and adversely affect plant growth and metabolism. $\mathrm{Cu}$ at a high concentration has higher toxicity than $\mathrm{Zn}$ [12]. This can also be reflected by the definition of $\mathrm{Cu}$ and $\mathrm{Zn}$ hyperaccumulator plants. Hyperaccumulation of $\mathrm{Cu}$ was defined as $>300 \mathrm{ppm}$ foliar $\mathrm{Cu}$ [32]. Zn hyperaccumulator can accumulate $>10,000 \mathrm{ppm}$ in aerial parts [20]. The germination index of brown and black seeds reached 81.2 and 47.5, respectively, at $10 \mathrm{mM} \mathrm{Cu}$, but the germination index of brown and black seeds was 94.9 and 61, respectively, at the same concentration of $\mathrm{Zn}$. Furthermore, at the seedling growth stage, the radicle tolerance indexes of brown and black seeds were 30.65 and 45.7 , respectively, at $0.1 \mathrm{mM}$ $\mathrm{Cu}$, but that were 68.61 and 70.81 at $0.1 \mathrm{mM} \mathrm{Zn}$. S. salsa seeds had high $\mathrm{Cu}$ and $\mathrm{Zn}$ tolerance during germination. Even at $100 \mathrm{mmol} \mathrm{L}^{-1} \mathrm{Cu}$ and $\mathrm{Zn}$, the germination percentages of both types of seeds were higher than $65 \%$. Germination percentages of most plant species significantly decline under $0.5 \mathrm{mM} \mathrm{Cu}$ and $\mathrm{Zn}[14,33]$. However, germination of $S$. salsa seeds did not show a significant difference until under $5 \mathrm{mM} \mathrm{Cu}$ and $\mathrm{Zn}$. Seedlings of $S$. salsa did not show obvious toxic symptoms under $0.1 \mathrm{mM}$ $\mathrm{Cu}$ and $1 \mathrm{mM} \mathrm{Zn} \mathrm{(Figure} \mathrm{3).} \mathrm{Thus,} \mathrm{S.} \mathrm{salsa} \mathrm{was} \mathrm{tolerant} \mathrm{to} \mathrm{high} \mathrm{concentrations} \mathrm{of} \mathrm{Cu}$ and $\mathrm{Zn}$ at the germination and seedling stages.

Among all the indexes, radicle length and radicle tolerance index are more sensitive to $\mathrm{Cu}$ and $\mathrm{Zn}$. Germination percentage and germination index are insensitive to metal stress, especially under $\mathrm{Zn}$ treatments. For black seeds, germination percentages and indexes did not significantly change under 0 to $300 \mathrm{mM} \mathrm{Zn}$. Compared with the indexes of germinated seeds, the indexes of seedlings were more sensitive to metal stresses. With the increase in metal concentration, indexes of seedlings decrease gradually. For example, the radicle tolerance index of black seeds decreased from 100 to 48 when the $\mathrm{Zn}$ concentration changed from control to $0.5 \mathrm{mM} \mathrm{Zn}$. It was also found that the indexes of radicle were more sensitive to metal stresses than those of shoot. For example, the radicle tolerance index of brown seeds was 24 under $1 \mathrm{mM} \mathrm{Cu}$ and the shoot tolerance index of brown seeds was 58 under the same $\mathrm{Cu}$ concentration. This high sensitivity of radicles can be explained by the fact that the radicle is the first part of a seedling to suffer from metal toxicity. Thus, when selecting high metal-tolerant halophytes, we should test not only the tolerance indexes of seeds and adult plants but also the indexes of seedlings. 


\section{Conclusions}

In summary, this study shows that indexes of radicle are the most sensitive and effective indicator of metal tolerance for germinating seeds of $S$. salsa. These indexes may also serve as a useful index for future research on the tolerance of different metals for plants during germination and seedling growth stages. The present study demonstrates that dimorphic seeds of $S$. salsa are able to germinate under high $\mathrm{Zn}$ and $\mathrm{Cu}$ concentrations. However, seedling growth, especially the radicle growth, is more sensitive to the same level of metal stress. Overall, successful germination and survival of seedlings of S. salsa under medium $\mathrm{Zn}$ and $\mathrm{Cu}$ metal stress has been proved. Thus, this plant species might provide an important contribution to phytoremediation by sowing seeds directly into heavy metal contaminated soils.

Author Contributions: Conceptualization, L.W. and L.J.; investigation, H.Z. and L.J.; writing—original draft preparation, H.Z., L.J and L.W.; writing—review and editing, M.T., J.M., Z.Z. and L.W.; visualization, H.Z. and L.W.; project administration, L.W.; funding acquisition, Z.Z. All authors have read and agreed to the published version of the manuscript.

Funding: This research was funded by the National Key Research and Development Program of China (grant number 2018YFE0207200) and the Strategic Priority Research Program of the Chinese Academy of Sciences (grant number XDA2003010302).

Conflicts of Interest: The authors declare no conflict of interest.

\section{References}

1. Hussain, S.; Khaliq, A.; Noor, M.A.; Tanveer, M.; Husssin, H.A.; Hussain, S.; Shah, T.; Mehmood, T. Metal toxicity and nitrogen metabolism in plants: An overview. In Carbon and Nitrogen Cycling in Soil; Datta, R., Meena, R.S., Pathan, S.I., Ceccherini, M.T., Eds.; Springer: Singapore, 2020; pp. 221-248.

2. Muthusaravanan, S.; Sivarajasekar, N.; Vivek, J.S.; Paramasivan, T.; Naushad, M.; Prakashmaran, J.; Gayathri, V.; AI-Duaij, O.K. Phytoremediation of heavy metals: Mechanisms, methods and enhancements. Environ. Chem. Lett. 2018, 16, 1339-1359. [CrossRef]

3. Ali, H.; Khan, E.; Sajad, M.A. Phytoremediation of heavy metals-Concepts and applications. Chemosphere 2013, 91, 869-881. [CrossRef]

4. Ghori, N.H.; Ghori, T.; Hayat, M.Q.; Imadi, S.R.; Gul, A.; Altay, V.; Ozturk, M. Heavy metal stress and responses in plants. Int. J. Environ. Sci. Technol. 2019, 16, 1807-1828. [CrossRef]

5. He, J.; Ji, Z.X.; Wang, Q.Z.; Liu, C.F.; Zhou, Y.B. Effect of $\mathrm{Cu}$ and Pb pollution on the growth and antioxidant enzyme activity of Suaeda heteroptera. Ecol. Eng. 2016, 87, 102-109. [CrossRef]

6. Nedjimi, B. Germination characteristics of Peganum harmala L. (Nitrariaceae) subjected to heavy metals: Implications for the use in polluted dryland restoration. Int. J. Environ. Sci. Technol. 2020, 17, 2113-2122. [CrossRef]

7. Shang, C.L.; Wang, L.; Tian, C.Y.; Song, J. Heavy metal tolerance and potential for remediation of heavy metal-contaminated saline soils for the euhalophyte Suaeda salsa. Plant Signal. Behav. 2020. [CrossRef]

8. Wang, H.L.; Tian, C.Y.; Jiang, L.; Wang, L. Remediation of heavy metals contaminated saline soils: A halophyte choice? Environ. Sci. Technol. 2014, 48, 21-22. [CrossRef]

9. Van Oosten, M.J.; Maggio, A. Functional biology of halophytes in the phytoremediation of heavy metal contaminated soils. Environ. Exp. Bot. 2015, 111, 135-146. [CrossRef]

10. Gutterman, Y. Survival Strategies of Annual Desert Plants; Springer: Berlin, Germany, 2002.

11. Ye, N.; Li, H.; Zhu, G.; Liu, R.; Xu, W.; Jing, Y.; Peng, X.; Zhang, J. Copper suppresses abscisic acid catabolism and catalase activity, and inhibits seed germination of rice. Plant Cell Physiol. 2014, 55, 2008-2016. [CrossRef]

12. Pokorska-Niewiada, K.; Rajkowska-Myśliwiec, M.; Protasowicki, M. Acute lethal toxicity of heavy metals to the seeds of plants of high importance to humans. Bull. Environ. Contam. Toxicol. 2018, 101, 222-228. [CrossRef]

13. Li, W.; Khan, M.A.; Yamaguchi, S.; Kamiya, Y. Effects of heavy metals on seed germination and early seedling growth of Arabidopsis thaliana. Plant Growth Regul. 2005, 46, 45-50. [CrossRef]

14. Guterres, J.; Rossato, L.; Doley, D.; Pudmenzky, A.; Bee, C.; Cobena, V. Assessing germination characteristics of Australian native plant species in metal/metalloid solution. J. Hazard. Mater. 2019, 364, 173-181. [CrossRef] 
15. Yáñez-Espinosa, L.; Briones-Gallardo, R.; Flores, J.; Álvarez del Castillo, E. Effect of heavy metals on seed germination and seedling development of Nama aff. stenophylla collected on the slope of a mine tailing dump. Int. J. Phytoremediation 2020. [CrossRef]

16. Nanda, R.; Agrawal, V. Elucidation of zinc and copper induced oxidative stress, DNA damage and activation of defence system during seed germination in Cassia angustifolia Vahl. Environ. Exp. Bot. 2016, 125, 31-41. [CrossRef]

17. Liu, X.; Shen, X.; Lai, Y.; Ji, K.; Sun, H.; Wang, Y.; Hou, C.; Zou, N.; Wan, J.; Yu, J. Toxicological proteomic responses of halophyte Suaeda salsa to lead and zinc. Ecotoxicol. Environ. Saf. 2016, 134, 163-171. [CrossRef] [PubMed]

18. Marschner, P. Marschner's Mineral Nutrition of High Plants, 3rd ed.; Science Press: Beijing, China, 2013.

19. Lange, B.; van der Ent, A.; Baker, A.J.M.; Echevarria, G.; Mahy, G.; Malaisse, F.; Meerts, P.; Pourret, O.; Verbruggen, N.; Faucon, M.P. Copper and cobalt accumulation in plants: A critical assessment of the current state of knowledge. New Phytol. 2016, 213, 537-551. [CrossRef] [PubMed]

20. Balafrej, H.; Bogusz, D.; Triqui, Z.-E.A.; Guedira, A.; Bendaou, N.; Smouni, A.; Fahr, M. Zinc hyperaccumulation in plants: A review. Plants 2020, 9, 562. [CrossRef] [PubMed]

21. Song, J.; Wang, B. Using euhalophytes to understand salt tolerance and to develop saline agriculture: Suaeda salsa as a promising model. Ann. Bot. 2015, 115, 541-553. [CrossRef]

22. Wang, F.L.; Song, N.N. Salinity-induced alterations in plant growth, antioxidant enzyme activities, and lead transportation and accumulation in Suaeda salsa: Implications for phytoremediation. Ecotoxicology 2019, 28, 520-527. [CrossRef]

23. Jiang, L.; Wang, L.; Zhang, K.; Tian, C.Y. Copper-induced similar changes in growth and physiological responses of plants grown from dimorphic seeds of Suaeda salsa. Pak. J. Bot. 2018, 50, 871-877.

24. Song, J.; Fan, H.; Zhao, Y.; Jia, Y.; Du, X.; Wang, B. Effect of salinity on germination, seedling emergence, seedling growth and ion accumulation of a euhalophyte Suaeda salsa in an interidal zone and on saline inland. Aquat. Bot. 2008, 88, 331-337. [CrossRef]

25. Liu, S.; Yang, C.; Xie, W.; Xia, C.; Fan, P. The effects of cadmium on germination and seedling growth of Suaeda salsa. Procedia Environ. Sci. 2012, 16, 293-298. [CrossRef]

26. Wan, Z.; Gao, T.; Zhou, Y.; Wang, Y.; Chang, G.; Ju, T.; Yang, Y.; Zhang, Q. Seed germination, bud growth and heavy-metal accumulation of Suaeda salsa. Chin. J. Biotechnol. 2020, 36, 493-507, (In Chinese with English Abstract). [CrossRef]

27. Ajmal, K.M.; Gul, B.; Weber, D.J. Germination of dimorphic seeds of Suaeda moquinii under high salinity stress. Aust. J. Bot. 2001, 49, 185-192.

28. Zhang, K.; Yao, L.; Zhang, Y.; Tao, J. Achene heteromorphism in Bidens pilosa (Asteraceae): Differences in germination and possible adaptive significance. AoB Plants 2019, 11, plz026. [CrossRef]

29. Nisar, F.; Gul, B.; Khan, M.A.; Hameed, A. Heteromorphic seeds of coastal halophytes Arthrocnemum macrostachyum and A. indicum display differential patterns of hydrogen peroxide accumulation, lipid peroxidation and antioxidant activities under increasing salinity. Plant Physiol. Biochem. 2019, 144, 58-63. [CrossRef]

30. Payamani, R.; Nosratti, I.; Amerian, M. Variations in the germination characteristics in response to environmental factors between the hairy and spiny seeds of hedge parsley (Torilis arvensis Huds.). Weed Biol. Manag. 2018, 18, 176-183. [CrossRef]

31. Redondo-Gómez, S.; Mateos-Naranjo, E.; Cambrollé, J.; Luque, T.; Figueroa, M.E.; Davy, A.J. Carry-over of differential salt tolerance in plants grown from dimorphic seeds of Suaeda splendens. Ann. Bot. 2008, 102, 103-112. [CrossRef]

32. van der Ent, A.; Baker, A.J.M.; Reeves, R.D.; Pollard, A.J.; Schat, H. Hyperaccumulators of metal and metalloid trace elements: Facts and fiction. Plant Soil 2013, 362, 319-334. [CrossRef]

33. Boi, M.E.; Porceddu, M.; Cappai, G.; De Giudici, G.; Bacchetta, G. Effects of zinc and lead on seed germination of Helichrysum microphyllum subsp. tyrrhenicum, a metal-tolerant plant. Int. J. Environ. Sci. Technol. 2020, 17, 1917-1928. [CrossRef]

(C) 2020 by the authors. Licensee MDPI, Basel, Switzerland. This article is an open access article distributed under the terms and conditions of the Creative Commons Attribution (CC BY) license (http://creativecommons.org/licenses/by/4.0/). 